\title{
Summer Training Report on Customer Satisfaction towards Hero Honda
}

\author{
Nivedha, S.Praveen Kumar, Vinoth Kumar.S
}

\begin{abstract}
Two wheelers play a vital role in human life. The best mode of transport for middle class family is a two wheeler and is a need for everyone in the family. As people want increase their standard of living, the production and usage of two wheelers have also substantially increased.

The customer's preference for two wheeler is based on his taste and priorities. In a market oriented economy the consumer expect the right type and the right quality of goods at the right time and at the right price. As a result of the new licensing policy and allowing foreign collaboration, number of high technology and fuel efficient two wheelers are manufactured.

The study is about the special features and qualities of Hero, the different model available in the market which attract the customer, the reason for the usage of Hero, the services provided by the Hero dealers and customers satisfaction.
\end{abstract}

\section{INTRODUCTION}

Transportation means the physical movement of persons and good from one place to another. In olden days, people who want to travel from one place to another would walk in groups or go in horses, bullock cart etc. This was really tired and would take long time to reach destination, but now various automobiles are available like two wheelers, three wheelers and four wheelers. Two wheelers may be scooters, bikes and these are called so as they have two wheels. [19],[21],[23]

Today two wheelers have become an indispensable part of the lives as it is faster, cheaper and inconvenient. Two wheelers are used for attending to work related activities, useful for shopping, to drop the children at the school, for convenient travelling in the city and they gives social status prestige to the two wheeler consumers.

In India two wheeler industries make a small beginning in the early 50's when automobiles product of India started manufacturing scooters in the country. Until 1958, automobiles products of India and Enfield were the sale producers in 1948, Baja auto began trading in imported Vespa scooters and there wheelers. [26],[28],[30]

Finally in 1960 , it set up a factor to manufacture them in technical collaboration with piaggio of Italy. Even though there are various government and private companies entered in the two wheeler production, Bajaj is the best among all the other companies. Other important bike manufactures are Enfield, Bullet, Java and Rajdoot.

Revised Manuscript Received on July 22, 2019.

Nivedha , Department of MBA,Bharath institute of Higher Education \& Research,Tamilnadu,India Email:nivedha@gmail.com

Dr.S.Praveen Kumar, Department of MBA,Bharath institute of Higher Education \& Research,Tamilnadu,India Email: praveenkumar.mba@bharathuniv.ac.in

Vinoth Kumar.S, Department of Civil,,Bharath institute of Higher Education \& Research,Tamilnadu,India Email: vinothsenna @ gmail.com
The two wheeler market was high during 1980's with the entry of Kinetic Honda with a variometricscooty helped in providing ease of use to the scooter owners and how there are verities of two wheelers like scoot pep, Honda active, Hero Honda etc.

Today students, workers, officers etc are increasing in numbers day to day in both urban and rural areas. The standard of living has also increased in recent year's leading to people travel from one place to another for work and leisure. Majority of the suburbs were not served by mass transit, the population shift created an attractive market for automobile manufacturer. The number of vehicle produced and sold increased dramatically. [20],[22], [24]

\section{OBJECTIVES OF THE STUDY}

The present study has the following objectives.

1. To assess the brand preference of two wheelers among the respondents.

2. To assess the factors motivating the individuals to buy a particular brand.

3. To find out the mode of purchase of two wheelers.

4. To analyze after sales service provided by dealers

5. To find out the problems faced by the respondents in using two wheelers.

6. To give suggestions based on the findings. [25],[27],[29]

\section{RESEARCH METHODOLOGY}

This study is an imperial study combining the use to both primary and secondary data.

\section{(a) Primary Data}

Primary data is collected by conducting field investigation with the help of well-designed questionnaire and personal interview with the customers.

(b) Secondary Data

The secondary data were collected from published sources like, various books, magazines, journals, statistics reports, websites, past thesis.

\section{A. SELECTION OF SAMPLES}

Data have been collected from 120 respondents of the study area. Each sample respondents is interview with the help of questionnaire.

\section{B. PERIOD OF STUDY}

The field work for this study was carried on two months from May 2016 to June 2016. 


\section{STATISTICAL TOOLS OF ANALYSIS}

To make the present research study highly effective and fruitful the following statistical techniques were used for the purpose of collection analysis and interpretation of data. For selecting respondents, convenience sampling technique was used. The collected information was presented in a master table and then the separate tables like 5 points scaling technique has been used to analyze customer's satisfaction towards Hero. [8],[10] ,[12]

\section{LIMITATIONS OF THE STUDY}

The study pertains to Vilavancode Taluk in five villages only. So the finding and conclusion may not be applicable to anther Taluk.

The study emphasis only on motorized two wheelers. It does not make any suggestion or comments on "Bi-cycles" or "other vehicles".

This study gives more importance to the customer side, and it does not give much importance to production or marketing aspect of the two wheelers. [2 ],[ 4],[6]

\section{REVIEW OF LITERATURE}

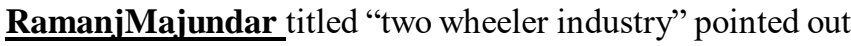
that the sample consumers perceived Hero as fuel efficiency, TVS as a high pick up, Hero Honda M 60 as high pick up and sleek model and finally Suzuki as smooth trouble free and good value of money. The study has provided that to identify the opinion and reaction of consumer of the particular brand two wheeler. [13], [15] ,[ 17]

RanjanaPendharkar in his articles says that the vehicles growth in the economic scene reveals that the transport sector not only helps in the service sector but it also helps in enhancing productivity. In these days even economic activity is stimulated by the transport sector.

\section{RESULTS}

In this chapter the researcher had summarized the findings, suggestions and presented the conclusion.

$>$ The study reveals that, most of the respondents belong to the group of above 45 .

$>$ The study reveals that, majority of the respondents are male.

$>$ The study discloses that most of the respondents were married [1],[3],[5]

$>$ The study reveals that the level 6 education among the respondents is school level.

$>$ The study discloses that, most of the respondents were monthly income of Rs. 10000 - Rs. 20000.

$>$ The study reveals that, the majority of the respondents are known about Hero through friends.
$>$ The study discloses that, most of the respondents are purchase of Hero in a company show room.

$>$ The study reveals that, the majority of the respondents have changes in Hero models.

$>$ The study reveals that, most of the respondents say the reason for selection of engine capacity.

$>$ The study discloses that, most of the respondents are changing the vehicle.

$>$ The study exhibits that, the majority of the respondents says reason for changing of Low engine capacity.

$>$ The study reveals that, majority of the respondents are says that mileage vehicle is $31 \mathrm{~km}-35 \mathrm{~km}$

$>$ The study discloses that, most of the respondents were use of fuel per month is $10 \mathrm{ltr}-20 \mathrm{ltr}$ [7],[9] ,[11]

$>$ The study discloses that, most of the respondents were buying the Hero for motivated as the new model and Mileage.

$>$ The study reveals that, most of the respondents are purchased a new vehicle.

$>$ The study shows that, most of the respondents were purchased the vehicle by ready cash.

$>$ The study reveals that, the majority of the respondents are purchased the vehicle at a price level of Rs. 50000 - Rs. 60000

$>$ The study shows that, most of the respondents have the opinion about the price level is low.

$>$ The study shows that, the majority of the respondents are availing loans from Mahindra finance.

$>$ The study reveals that, the majority of the respondents are satisfied with the performance of vehicle.

$>$ The study discloses that, most of the respondents are satisfied with the activities are customer service.

$>$ The study reveals that most of the respondents are taking the insurance policy for their vehicle

\section{DISCUSSION}

* Company can provide guarantee for at least three years.

* Company can introduce the new model and reduce the price of Hero.

* The company expects more varieties and colors.

* Free helmet can be providing to the customer at the time of purchase.

* Company can provide interest free loans for purchasing the Hero.

* Automatic alarm must be fixed to all the vehicles to avoid fuel wastage the theft.

* Attractive gifts can be provided to customer at the time of purchasing.

\section{CONCLUSION}

In this area of industrial growth, every day a new vehicle is coming in the market. This study was conducted with the aim to learn about the customer satisfaction towards Hero among the respondents it covers the objectives of identifying the customer's expectation towards Hero. These vehicles are introduced through advertisement both in rural and urban market. The demand for the existing form, design etc. The dealers and suppliers use various sales promotions techniques to increase the sales volume. Because of all these efforts the Hero finds it easy to create a new customer and to retain the existing customer. Lack 
of purchasing power and poor financial conditions are the main problem based by the customer presently. So after sales services should be improved a new model vehicle should be introduced to all the requirements of middle class people, so that they can satisfy the needs of all types of customers.

\section{REFERENCES}

1) BharthVajan R., Ramachandran S.,Psychographic dimensions of training,2016,International Journal of Pharmacy and Technology,V-8,I-4,P-23727-23729

2) Balakrishnan P., Bharthvajan R.,A study on human resource planning in hospitals in Chennai City,2014,International Journal of Applied Engineering Research,V-9,I-22,P-7503-7507

3) Priyadarsini P., Bharthvajan R.,Role of emotional intelligence training programme in reducing the stress of the nurses,2014,International Journal of Applied Engineering Research,V-9,I-22,P-7411-7421

4) Kerinab Beenu G., Bharthvajan R.,Empirical analysis on the cosmetic buying behavior of young women in South India,2014,International Journal of Applied Engineering Research,V-9,I-22,P-7361-7366

5) Balakrishnan P., Bharthvajan R.,Whistling in the wind,2014,International Journal of Applied Engineering Research,V-9,I-22,P-7586-7593

6) Krishnan B., Peter M.,Health hazards of Indian Bpo employee-an alarming issue,2014,International Journal of Applied Engineering Research,V-9,I-22,P-7336-7341

7) Kerinab Beenu G.H., Peter M.,Role of insurance in economic development,2014,International Journal of Applied Engineering Research,V-9,I-22,P-7532-7539

8) Balakrishnan P., Peter M., Priyadarsini P.,Efficiency of safety measures for wellbeing of employees in manufacturing industry,2014,International Journal of Applied Engineering Research,V-9,I-22,P-7376-7382

9) Anbarasi M., Praveen Kumar S.,Online sales promotions of herbal products and its effectiveness towards tanisha.com,2019,Indian Journal of Public Health Research and Development,V-10,I-1,P-195-200

10) Anbarasi M., Praveen Kumar S.,Various online marketing and promotions strategies to improve the validation towards the organic products in the pharmaceutical sectors,2019,Indian Journal of Public Health Research and Development,V-10,I-1,P-263-269

11) Loganathan R., Praveen Kumar S.,Grievance handling a key factor for solving issues of employees in an organization,2014,International Journal of Applied Engineering Research,V-9,I-22,P-7483-7491

12) Loganathan R., Praveen Kumar S.,Study on preference of private label brands in super and Hypermarkets,2014,International Journal of Applied Engineering Research,V-9,I-22,P-7327-7335

13) Smitha M., Praveen Kumar S.,Understanding stress and its managementamong the nurses in Chennai city,2014,International Journal of Applied Engineering Research,V-9,I-22,P-7560-7565

14) Kerinab Beenu G.H., Praveen Kumar S.,A study on the investment behavior of Chennai investors in mutual fund schemes,2014,International Journal of Applied Engineering Research,V-9,I-22,P-7520-7525

15) Loganathan R., Praveen Kumar S.,Retention strategies key for organizational productivity,2014,International Journal of Applied Engineering Research,V-9,I-22,P-7443-7447

16) Pavithra J., Ganesan M., Brindha G.,State wise analysis of microfinance sector in India,2016, International Journal of Pharmacy and Technology,V-8,I-4,P-23417-23432

17) Pavithra J., Ganesan M.,A comparative study on microfinance in India and abroad,2016,International Journal of Applied Business and Economic Research,V-14,I-8,P-5471-5476

18) Pavithra J., Ganesan M.,A study on awareness and impact of micro-financial schemes,2016,International Journal of Applied Business and Economic Research,V-14,I-8,P-5449-5460

19) Senthilmurugan P., Pavithra J.,Consumer preference towards organised retailing with reference to Big Bazaar,2014,International Journal of Applied Engineering Research,V-9,I-22,P-7469-7475

20) Senthilmurugan P., Pavithra J.,Implication of social media marketing in growing healthcare industry,2014,International Journal of Applied Engineering Research,V-9,I-22,P-7448-7456

21) Loganathan R., Pavithra J.,Consumer perception towards private label brand over other brands in super markets and hypermarkets,2014,International Journal of Applied Engineering Research,V-9,I-22,P-7355-7360

22) Kerinab Beenu G., Pavithra J.,Tradeâ€"off between liquidity and profitability in logistics industry,2014,International Journal of Applied Engineering Research,V-9,I-22,P-7398-7401
23) Kerinab Beenu G., Pavithra J.,A study on the prospective consumerâ€ $€^{\mathrm{TM}_{\mathrm{S}}}$ perception towards utility cars in Chennai city,2014,International Journal of Applied Engineering Research,V-9,I-22,P-7526-7531

24) Pavithra J., Dilli Babu P., Ambuli T.V.,A study on budgetary control at Maruti Service Masters, Chennai,2014,International Journal of Applied Business and Economic Research,V-12,I-2,P-151-161

25) Pavithra J., Dilli Babu P., Ambuli T.V.,A study on customer satisfaction of retro Garments Pvt Ltd, Chennai,2014,International Journal of Applied Business and Economic Research,V-12,I-2,P-381-391

26) Kerinab Beenu G.H., Pavithra J., Senthilmurugan P.,A study on the influence of promotional activities for TATA ARIA among consumers in Chennai,2014,International Journal of Applied Engineering Research,V-9,I-22,P-7572-7578

27) Vijayaragavan S.P.,An investigative expert that's general FBG sensors,International Journal of Mechanical Engineering and Technology,V-8,I-8,PP-1500-1505,Y-2017

28) Vijayaragavan S.P.,Equalization routing protocol for Wi-Fi sensor strategy,International Journal of Mechanical Engineering and Technology,V-8,I-8,PP-1662-1666,Y-2017

29) Karthik B., Kiran Kumar T.V.U., Vijayaragavan P., Bharath Kumaran E.,Design of a digital PLL using 0.35 $\hat{\mathrm{I}}^{1 / 4 \mathrm{~m}}$ CMOS technology, Middle East Journal of Scientific Research,V-18,I-12,PP-1803-1806,Y-2013

30) Kanniga E., Selvaramarathnam K., Sundararajan M.,Kandigital bike operating system,Middle - East Journal of Scientific Research,V

31) Jasmin M., Vigneshwaran T., Beulah Hemalatha S.,Design of power aware on chip embedded memory based FSM encoding in FPGA,International Journal of Applied Engineering Research,V-10,I-2,PP-4487-4496,Y-2015

32) Jasmin M.,Optimization techniques for low power VLSI circuits,Middle East Journal of Scientific Research,V-20,I-9,PP-1082-1087,Y-2014

33) Jasmin M., Vigneswaran T.,Fuzzy controller for error control of on - Chip communication,2017 International Conference on Algorithms, Methodology, Models and Applications in Emerging Technologies, ICAMMAET 2017,V-2017-January,I-,PP-1-5,Y-2017

\section{AUTHORS PROFILE}

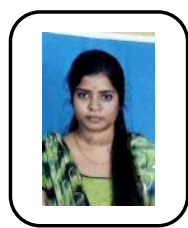

Nivedha , Department of MBA,Bharath institute of Higher Education \& Research,Tamilnadu,India

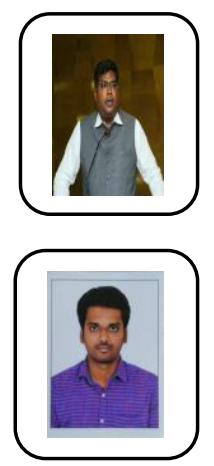

Dr. S.Praveen Kumar, Department of MBA,Bharath institute of Higher Education \& Research,Tamilnadu,India

Vinoth Kumar.S, Department of Civil,,Bharath institute of Higher Education \& Research,Tamilnadu,India 